\title{
Shipping policy of agri-food products and the formation of food markets in Georgia
}

\author{
Eteri Kharaishvili ${ }^{1 *}$, Badri Gechbaia ${ }^{2}$, Gulnaz Erkomaishvili ${ }^{1}$, Manana Lobzhanidze $^{1}$, and \\ Ia Natsvlishvili ${ }^{1}$ \\ ${ }^{1}$ Ivane Javakhishvilli Tbilisi State University, Faculty of Economics and Bussiness, 1 Chavchavadze \\ avenue, 0179 Tbilisi, Georgia \\ ${ }^{2}$ Batumi Shota Rustaveli State University, Department of Business Administration, Management and \\ Marketing, Ninoshvili/Rustaveli str. 35/32, Batumi, Georgia
}

\begin{abstract}
The article evaluates an importance of shipment in economic growth and the development of food markets. Delays caused in shipment of agri-food products due to the COVID-19 pandemic are analyzed, problems in logistics are identified. It is argued that by identifying challenges in the shipment system and developing effective policy mechanisms, it is possible to create food markets that meet the changing requirements. The qualty of impact-emergency matrix identifies challenges in food shipment policy: weak political support, legislative vacuum on shipping and food market standards, non-compliance of regulatory rules with regulations of other countries, low level of digitalization of shipments, policies to maintain food prices in case of increase in shipment costs, etc. The article concludes that the correlation between food production and its shipment rates is positive, however, insufficient to impact economic growth. Pursuing a transport-stimulating policy will lead to the diversification of the food markets, especially in European markets. Considering the development of the food market and the challenges identified in the field of shipment policy, recommendations have been developed towards policy priorities and directions of the development of food markets.
\end{abstract}

\section{Introduction}

Shipping business in any country of the world is characterized by a high rate of development. Transportation and logistics plays significant role in sustanble development. Sustainable development is a development that meets the needs of the present without compromising the ability of future generations to meet their own needs [1]. It is based on three pillars: economic, social, and environmental. Sustainable development for transportation systems face main challenges: non-inclusive development, air pollution, adverse health and social impacts, road safety, growing demand, energy consumption and other resources.

\footnotetext{
${ }^{*}$ Corresponding author: eter.kharaishvili@tsu.ge
} 
Transport policy decisions made today will have a huge impact on humans's life security in the future. United Nations Center for Regional Development addresses the need for an integrated approach to manage with social, economic, and environmental issues associated with the transportation and logistics sector. Since 2004, has been promoting Environmentaly Sustanble Transport concept [2]. There is no single definition of this concept, but it is centered on the transportation system and transportation activity that meets social, economic and environmental objectives. Air pollution from the transportation sector, growing vehicle ownership, urbanization trend threetens to undermine human health, the urban environment, economic productivity, and social equity. Sustainable transportation methods considers the means by which transportation takes place in line with the principles of sustainability, it is necessary to integrate three specific areas: economic equity, the environment, and social development [3].

Georgia has historically been a corridor between Europe and Asia in terms of shipment. One of the competitive advantages of Georgia is its transit function, which, together with natural-climatic conditions, intellectual resources and other factors, should ensure the development of business in the country and increase the competitiveness of the economy [4]. Due to its favorable geographical location, Georgia has the opportunity to play a key role of a transit corridor, to integrate its transport and logistics systems into international logistics systems and thus contribute to the overall economic development of the country. Ivestments play key role for the development of transit systems in Georgia and it successful integration into the world economy. Investments in the transport and logistics infrastructure of OECD member and partner states with transit function and sea access (among them Georgia) are highly effective in stimulating the transport and logistics sector itself. Such investments also play a very positive role in the socio-economic development of the country [5].

In ensuring sustainable development "An international integrated intermodal transport and logistics system" endorsed by the United Nations [1] plays the significant role. This system is based on the intermodal network of well designed, maintained and interconnected highways, railways, inland waterways, sea ports, river ports, airports or dry ports. The system combines the advantages of each mode of transport to achieve the balanced integration of economic, social and environmental benefits. Based on modal shift the system optimizes the needs of transporting goods and passengers, minimizes consumption of energy, land and other resources, generates low emissions of, greenhouse gases and ozone depleting substances, minimizes the adverse social impacts arising from transport operations. Shipment plays an important role in economic growth. It is closely linked with the development of the agricultural sector that can make a significant contribution to economic growth and poverty alleviation, especially in developing countries [6]. Researchers argue that structural transformation of the sector is critical to the sustainable production of agri-food products. It is necessary to mobilize resources and to encourage innovation policies in the food supply system [7]. Agrifood supply chains are distinguished from other industrial manufacturing and service supply chains by several characteristics: risk emanating from the biological nature of agrifood supply chains, the role of buffer stocks within the supply chain, the scientific foundation of innovation in production agriculture having shifted from chemistry to biology, cyberspace and information technology influences on agrifood supply chains, the prevalent market structure at the farm gate remains oligopsony, relative market power shifts in agrifood supply chains away from food manufacturers downstream to food retailers, globalization of agriculture and agri-food supply chains [8]. At a global level the global food supply chain is connected to the transport network. During the pandemic this network slowed down, therefore the food supply is affected. The aviation industry was in a state of shock. This created an obstacles to the food supply chain and its growth in the short term [9]. 
Georgia's agricultural sector has the potential to produce and supply competitive agrifood products to the market [10]. One of the most important challenges for the country in the supply chain of agri-food products is the efficient shipment of agri-food products. It should be noted that the food sector is particularly "sensitive" in the Georgia's economy, as food is consumed by all consumers, including those living below the poverty line. Therefore, it is important to ensure that food prices remain stable. Rising prices on these products will lead to the decrease of purchasing power of the population in the face of unchanged income. Rising food prices often exceed the subsistence level, and it is the price change that is the main challenge for the food security of Georgia [11].

The share of food expenditures in Georgia in the total consumer basket is $43 \%$ [12]. The problem is exacerbated by the fact that Georgia is heavily dependent on imported food. Researchers believe that the need for applying food pricing policies is even more acute in the middle-income countries. In case of both import and export of products, as well as for the effective trade at the global level considering price increases or reductions, appropriate policy mechanisms are needed [13].

Food prices have risen significantly and become more volatile in the last decade [14]. The sharp change in the prices has affected almost all types of products. The upward trend in prices is also observed for shipments. According to the National Statistics Office, in May, the producer price index for transport and warehousing services increased by $0.8 \%$ compared to the previous month. Prices for transport services in Georgia have increased by $2.9 \%$ [15]. Clearly, changes in shipping prices will affect food prices. It is therefore important to prioritize food shipment policies that reduce the impact of shipping costs on food prices.

Agri-food products are distinguished by the wide assortment. Due to the perishing of products it is important to use an optimal delivery system in a short time, so it is necessary to specialize shipping systems and to some extent centralize, consider the seasonality of the logistics system, marketing globalization and more. Efficient shipment of agri-food products, provision of appropriate logistics systems and technologies ares important factors for success for both producers and retailers on the one hand and consumers, on the other and as well as for the development of food markets in general.

The COVID-19 pandemic has created a number of logistics related problems that have had a significant impact on the long value chain of the modern global economy. The pandemic is the greatest challenge of a today's world. It poses a threat to the health of millions of people, causing unprecedented global economic mega-recession and uncertainty.

According to the Organization for Economic Cooperation and Development (OECD) [16], pandemic "lockdown" of the economy directly affects each sector of the economy and causes a reduction of almost one third of GDP in the world's leading economies (G20 countries). Lockdown causes a loss of $2 \%$ of annual GDP each month. According to the initial assessment of the World Bank, the pandemic and the lockdown of the leading economies can lead to extreme poverty for more than 60 million people. This fact means leveling of all the results achieved in the recent years for poverty eradication [17]. The real difficulties caused by the pandemic were exacerbated and researchers were forced to worsen their predictions. According to a later and more accurate assessment of the World Bank, The world has did a lot to reduce "extreme poverty in recent decades, but was not on track to reach the goal of ending it by 2030 even before the coronavirus hit. The pandemic could push about 100 million more people into extreme poverty in 2020. And by 2030, up to two-thirds of the world's extreme poor could be living in settings affected by fragility, conflict, and violence" [18]. The pandemic poses a particular threat on poor countries in terms of food security, as they have to import food in the event of a fall in their national currency, declining incomes, and difficulties in importing food into the country due to 
restrictions on export from that country and supply chain disruption [19]. The set of economic recovery measures should include measures aimed at: saving human lives, protecting the most vulnerable groups, reviving business activity and maintaining jobs, as well as creating a shock-resistant and flexible economy.

The pandemic and the measures taken to address it have created new challenges in the food transport system. Countries are faced with the task to achieve the smooth functioning of food markets and food supply chain to meet the growing demand for food. In order for the pandemic not to become the cause of a catastrophic food crisis, it is necessary to make appropriate decisions in accordance with the newly formed requirements of the entire agrifood production and supply chain, from which food shipment is of utmost important.

Efficient shipment of agri-food products will also play an important role in the development of food markets. Therefore, by identifying the challenges in the transport system and developing effective policy mechanisms, it will be possible to structure the food markets in accordance with the changed requirements.

Based on the above, the aim of the study is to develop recommendations on policy priorities and directions for the formation of food markets based on the identification of agri-food shipment policy challenges.

\section{Methods}

The research is based on the methods of analysis and synthesis, quantitative and qualitative, groupings, relative and average values, graphical representation, comparison, panel data analysis and others. In-depth interviews with experts were conducted to determine quantitative and qualitative indicators; The Impact-Emergency Matrix identifies barriers to food shipment and policy challenges; Priority schemes set the priorities for an economic policy to stimulate shipment.

Demand for agri-food products is growing worldwide and is gradually becoming global. The quantity, quality and safety of food often depend on the efficiency of food delivery systems. Since the second half of the 20th century, significant investments have been made in transport infrastructure, product storage technologies have been developed, large urban aggregates have been created as a result of global urbanization, and more. In general, the urbanization of the economy has brought about significant changes in the food distribution and shipment system. Demand for the food has grown exponentially and gained global scale. Accordingly, special attention has been paid by researchers to the creation of global freight distribution systems [20].

Transport infrastructure plays an important role in the development of agriculture. Scientists have substantiated the hypothesis that the developed transport system helps to increase productivity in agriculture. A country with better transport can produce more agrifood products [21]. Transport is a key factor that can play a crucial role in improving the economic performance of developing countries.

The role and importance of logistics in agri-food supply and supply chains is vital, which is also confirmed by empirical studies. Researchers place particular emphasis on farms and analyze their activities in the light of growing environmental, social and ethical requirements associated with agri-food supply chains [22].

The COVID-19 pandemic has made significant changes to shipment services. Scientists have assessed the impact of pandemic transport disruptions and new transport service requirements on the agri-food supply chain.

Scientists' analysis reveals that access to agri-food products by sea, rail and freight has generally improved during the pandemic. This is due to the declining demand for shipment of products from other sectors of the economy [23]. The pandemic caused significant disruptions in the food supply chain, which in turn affected the efficient functioning of food 
markets. The limited functioning of food markets poses a threat to the food security of the population. It is therefore important for the state to develop policy mechanisms that will facilitate the targeted movement of agri-food products towards local and global food markets, respond to challenges in the food supply chain, and reduce the negative effects of the pandemic [24]. The negative impact of COVID-19 for food supply chains is caused less from its impact on primary production or overall food demand than from its disruptive effects on the complex network of actors connecting farm to clients, and the unexpected change in the demand mix. Farm production has been affected by bottlenecks for inputs (most notably labour), processing has been disrupted by labour shortages and shutdowns, some modes of transport have been affected more than others, consumer demand has seen rapid and unprecedented shifts [25].

Shipment plays an important role in the smooth and sustainable functioning of food markets. The functioning and consistency of food markets are influenced by the forms and consistency of public policy coordination. Food market formation policy ensures effective links between producers and consumers that makes food more accessible through fiscal incentives [26]. The use of modern digital systems has a special impact on the value chain of agri-food products, especially on food shipment, as well as on agricultural policy instruments [27]. The share of small farms in the total number of farms in developing countries is high. The volume of products produced by small farms is very sensitive to shipment. Shipments of small volumes of product are often made by inadequate or poorly functioning vehicles with consequently low returns. A well-planned shipment system will enable small entrepreneurs to increase productivity, reduce shipment costs, strengthen social integration and improve the quality of life [28].

Studies have shown that it is important to observe safety measures and take into account the optimal time of shipment when transporting food, while preventive monitoring will significantly reduce the risks. However, these issues should be addressed using regulatory rules [29]. Among the challenges in the field of food shipment and distribution, researchers point to the need to expand the Internet and related infrastructure networks. This, in turn, will lead to the sustainability of logistics [30].

Considering the abovementioned, it is important to have a comprehensive view of the directions of shipment and food market development policy, in particular, the policy regarding transportation and regulation of internal food markets can include several areas, the most important of which are: Producer-oriented policy, which manifests itself in various forms of producer support (e.g. production subsidies); Customer-oriented policy, which involves influencing market operations measures (e.g. control of food stocks and prices); Shipping management policy (e.g. setting minimum and maximum shipping prices, stimulating food shipments); Funding policies in the field of digitization of shipments (e.g. acquisition of modern transport and management technologies, promotion of knowledge sharing);Development, monitoring of food safety and quality standards, etc.

\section{Results}

Modern studies have examined the existing barriers to the implementation of sustainable transport infrastructure policy and proposed practical recommendations for their elimination, including the formation of integrated transport agencies, policy development to regulate transport demand management, cost control for integrated development, and others [31].

The economic literature evaluates transport policy challenges and development directions. Emphasis is placed on the impact of transport investment and policy impact on economic growth in developing countries, as well as specific challenges for transport interventions are discussed [32]. 
In countries with developed economies, investment in shipping and improved technologies have led to a continuous reduction in spending on shipping, which has contributed to economic growth and, consequently, the further development of these countries. The current potential of shipping policy in low- and middle-income countries is not sufficient to promote sustainable and inclusive growth. Transport infrastructure is not properly developed, regulations in the transport sector are inadequate, the share of transport costs in total costs for food is high and appropriate policy instruments (subsidies, standards, taxes, incentive programs, etc.) are not applied.

In developing countries, special importance is attached to the economic policy of facilitating shipment, as these countries are characterized by asymmetric transport infrastructure. Scholars agree that the economic policies that facilitate shipment have a positive impact on food exports and consequently, on job growth in food companies. The scientists found that the road improvement program led to a significant increase in the average annual export growth rate of firms $(6.4 \%)$, followed by an increase in employment to $5.1 \%[33]$.

Rising food prices in recent years have been the subject of debate among scientists and politicians. In international food markets, price changes are seen as the main challenge to the food security [34].

Investments in transportation in Georgia can play a pivotal role in the loss-free and efficient movement of cargo from the production of agri-food products to consumers. In many cases, transport investments are inefficient and do not yield the expected results, especially with regard to the development of food markets. Given the scarcity of resources, it is necessary to prioritize transport and infrastructure policies, study the factors influencing the formation of transport policy, identify challenges in the field of shipment and work out ways to overcome them.

Analysis of the current structure of the supply chain in Georgia, evaluation of the role of producers, distributors, intermediaries, storage centers and other participants showed that one of the most important problems for the country is the reduction of delivery time from agri-food production to consumption [11]. At the same time, there are quite competitive food markets in Europe and Asia. Consequently, for any country, as well as for the manufacturer, the main task is to supply a competitive product to the market.

A study of the dynamics of cargo transported by the transport sector in Georgia showed that the volume of shipments did not change significantly in 2016-2020 (see Figure 1).

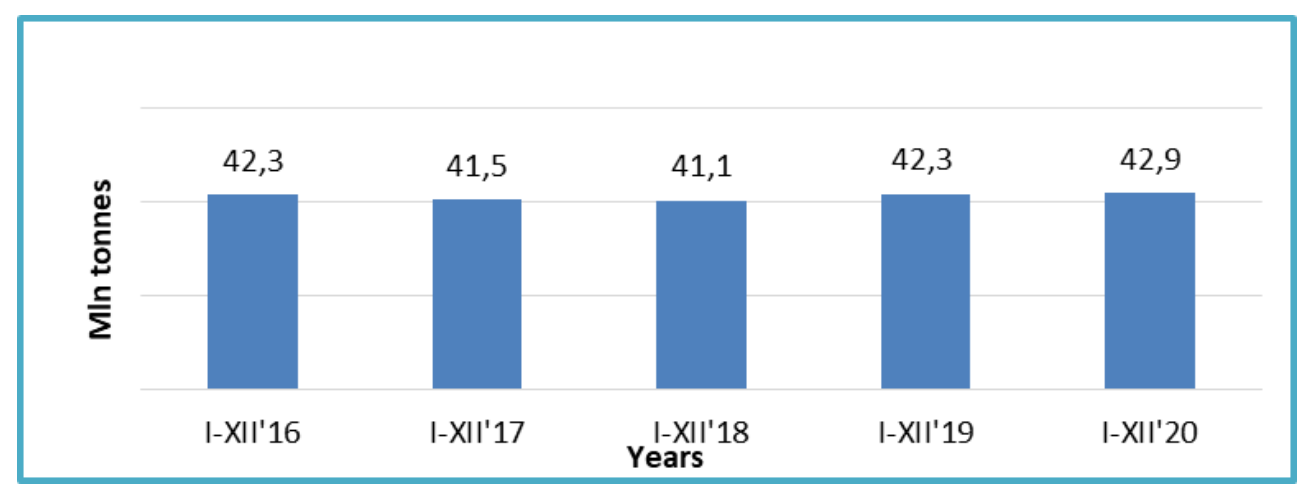

Fig. 1. Volume of cargo transported by transport sectors, million tons (total) in 2016-2020 [35].

As the diagram shows, in 2020, compared to 2016, the number of shipments of cargo increased by only 0.6 million tons. Cargo is transported by road as well as by rail and air (see Figure 2). 


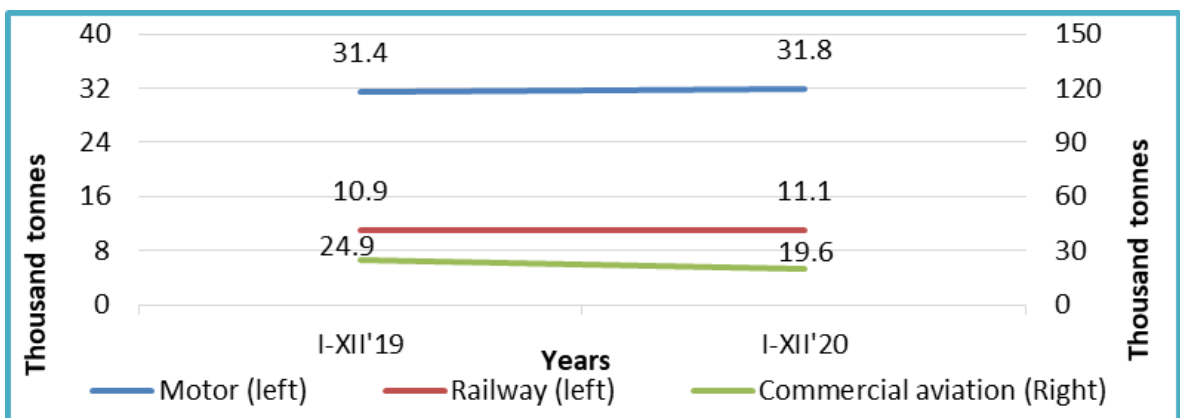

Fig. 2. Volume of cargo transported by transport sectors, million tons [35].

The diagram shows the dynamics of cargo transported by the transport sectors in the country in 2019-2020. The freight rate for both road and rail transport increased in 2020 compared to 2019, while air freight decreased due to the flight ban.

A crucial role in creating a developed transport system can be played the by developing effective mechanisms to stimulate shipping policies.

First of all, it should be noted that cargo shipment in Georgia is regulated by the relevant legislation and regulatory rules [36], however, the current legal framework is vague or imperfect.

Interviews with shipment managers showed that shipping companies have significant problems at this stage, including reduced shipping volumes and increased shipping services. It was also mentioned that in the conditions of the Coronavirus pandemic, the transport companies have to adapt not only to the regulations of Georgia, but also to the regulations of other countries, which makes their operations even more difficult.

A study of carriers has shown that due to the Covid 19 pandemic, some shipping companies in Georgia are completely shut down, some are only working on old orders. The new orders mainly come only for food and medical products. However, these orders are also difficult and delayed, and a limited number of products are supplied to the food markets. The main reason for this is the problems with the drivers (2-week quarantine after delivery, due to which companies are unable to take new orders), as well as increased time on delivery of goods (inspections due to various regulations, delays at the border, disinfection, etc.). Interviews with experts showed that shipping services have risen in price by about $20 \%$ due to the named problems [37].

Speaking about the trend of rising shipping prices, experts noted that the rise in prices will also affect food prices. According to experts, decisions must be made by the government so that the increase in transport costs does not have a significant impact on food prices.

The increase in shipping costs is primarily related to food prices and is related to food security for the population, so it is necessary to use government policy tools in this regard. In order to pursue a policy of maintaining food prices, in some cases it is necessary for the government to intervene in private business and impose restrictions.

In Georgia, as mentioned above, the volume of imports significantly exceeds exports. Clearly, under such conditions, the negative effects of the coronavirus impact on food prices are particularly large. In order to reduce the negative effects, 9 main types of products (rice, buckwheat, pasta, oil, flour, wheat, milk powder and sugar and beans) were subsidized in order to maintain stability of food prices in Georgia [38]. The subsidy will be provided in the amount that includes the cost of purchasing products and shipment to Georgia, and in the case of mixed goods, the cost of shipment will be taken into account in the appropriate proportion. 
The policy of maintaining food prices in this case is a policy of subsidizing producers. State will compensate companies the amount with which the manufacturer/importer firms have suffered. Like the tax, the benefit received from the subsidy is distributed between buyers and sellers. The nine products mentioned above are primary food products, consumers have an inelastic demand on them and it can be said that consumers will benefit more than manufacturers. Manufacturers are reaping the benefits as they sell their products at a higher price. Food pricing policies will be enacted in the short run, however, due to the economic crisis caused by the pandemic, when a large part of the population is unable to earn a living, pursuing a similar policy by the government will have a positive impact on improving the welfare of the population. This policy is mainly in line with the crisis period and therefore, the policy of maintaining food prices during the pandemic period is justified.

The increase in prices for the shipping service is caused by the extension of the transit terms, as well as the increased delays at the borders. It is well known that many countries have banned the export of certain products, checking this takes time and has a negative impact on shipping terms. Increased demand and reduced quantities of shipments lead to higher prices [37].

Improving the transport system significantly increases market access, which in turn is directly related to the growth of agricultural production [39]. Relevant studies have also found that a 1 percent increase in market access in the country leads to a 0.03 percent increase in GDP per capita [40].

Improving shipment can lead to a relatively even distribution of production across the transport network. Scientists emphasize that the named process affects the clustering of the activities of companies supplying raw materials and food, resulting in increased productivity in terms of economic growth and the development of food markets [41].

We used the Emergency-Impact Quality Matrix to identify challenges in food shipment policy (see Figure 3).

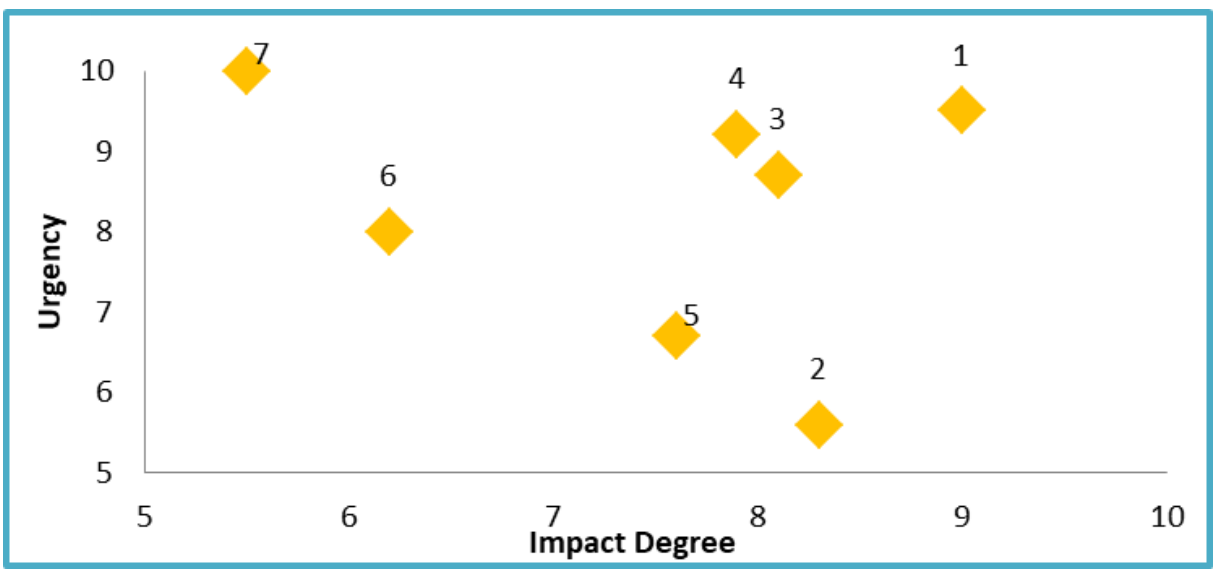

Fig. 3. Degree of emergency-impact.

By the grouping of materials according to the uniformity, the following challenges were identified in the field of food shipment policy in Georgia:

(1) weak political support for food shipment;

(2) a legislative vacuum on food transport and food market standards, as well as a lack of information on existing scant standards;

(3) non-compliance of Georgian transport regulatory rules with the regulations of other countries;

(4) a small number of innovative carrier companies that would be able to quickly adapt and respond to the changing market environment; 
(5) Low level of use of digital technology in the shipment system.

(6) Lack of the innovative infrastructure for shipment of food, low level of use of modern technologies;

(7) Food price maintenance policy in the event of an increase in costs of shipment.

It is important to develop economic policy mechanisms to stimulate shipment in order for food markets to function effectively.

We used the "Priority Scheme" to prioritize economic policies to stimulate shipment.

The following main areas were identified as economic policy priorities based on the interviews with the experts (see figure 4).

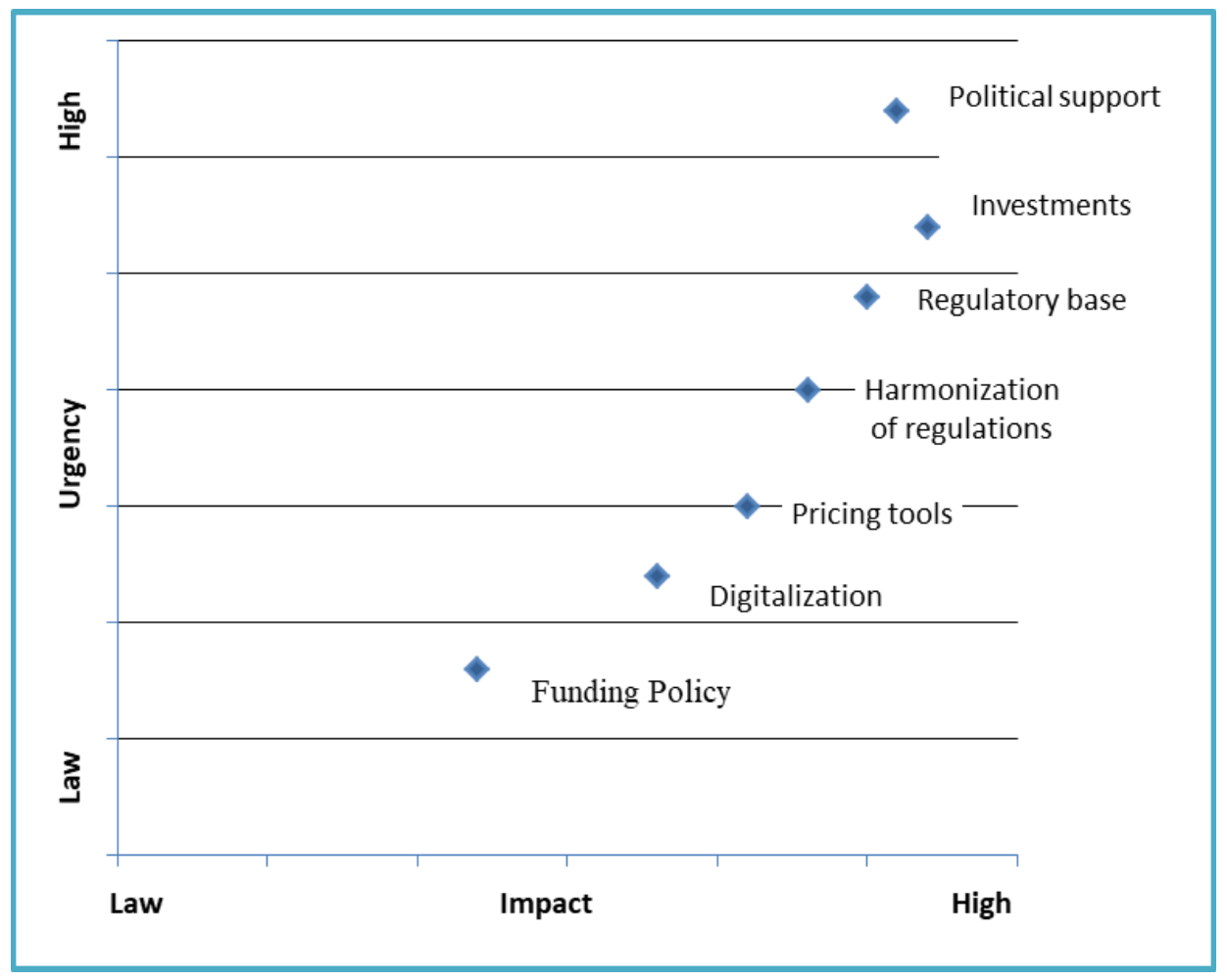

Fig 4. Economic Policy Priorities to Stimulate Shipment of Agri-Food Products

Several key priorities in the field of shipment policy have been identified: 1 . The need for political support for food shipment; 2. Investment in the development of shipping infrastructure; 3. Creation / improvement of the shipping regulatory base; 4. Harmonization of the shipping regulatory rules of Georgia with the regulations of other countries; 5. Use of pricing tools in food shipments; 6 . Digitalization of the shipment system and the transport corridor; 7. Provide funding policies to maintain a unified chain of shipping and food markets, etc.

Political support is considered to be one of the main priorities of the economic policy to stimulate food shipment. An important direction was the need to continue the investment supporting policy in transport infrastructure, as well as not only to eliminate the ambiguity of the legal framework and create regulatory rules, but also to harmonize shipping regulations with market standards and the legal space of Europe and other countries. 
Political interference will affect the supply of food and the development of food markets, for example by making targeted investments in transport infrastructure. In this regard, given the broad objectives of shipping policy, key directions may be to stimulate growth in food production. If shipping costs are low, this will lead to structural changes in the manufacturing and service sectors, increased productivity, the emergence of new industries, creating an agglomeration effect, providing trade incentives, making shipment available, and so on. Clearly, all of the above will help increase the economic opportunities of the low-income population and improve the welfare of the population in general. Achieving the stated goals will depend on the behavior of food firms and households in response to the policy intervention mechanisms.

Farmers in Georgia lack access to food markets, the main reason for this is that they can not use modern shipping systems, modern production technologies, as well as the their demand for targeted vehicles aren't met due to the underdeveloped supply chain. Food shipment will be substantially improved due to the supply chain perfection. In this regard, it is important that the chain of buyer and seller in food delivery is short, which will also lead to the establishment of new relationships between food stocks and the consumers. It is important to reduce food losses, as this figure is $30-40 \%$ of the total amount of food, half of which comes from shipment losses. As a result, large quantities of products are not supplied to consumers in the food markets.

The study of the availability of food markets in Georgia showed that the food markets in Tbilisi are unevenly distributed, the unequal distribution in the regions is even more pronounced, therefore one of the ways in improving the shipping system should be developing a food market access policy [42-44]. To ensure greater access to food markets for small farmers, it is essential to develop road systems and appropriate vehicles, especially in the highlands.

In stimulating food market development policies, it is important to increase access to information on markets and targeted vehicles and to close the information vacuum. Creating and delivering comprehensive information packages to beneficiaries, as well as increasing the frequency of deliveries, will contribute to the efficiency of food shipments and the expansion of food markets.

Priorities for price incentives include subsidies or taxes that may affect shipment and shipping behavior, such as food subsidies, fuel tax subsidies, and more.

Pursuing a shipment-stimulating policy will lead to the diversification of food markets, especially in European markets. The correlation between food production and its shipment rates is positive, however, insufficient to impact economic growth. It is important for economic growth to use effective mechanisms to stimulate shipping. The selection of transport policy mechanisms should be made in accordance with the development perspectives of the food market.

\section{Conclusions}

Shipment infrastructure creates conditions for the formation of the local and national food markets. On the one hand, the effective work of agri-food companies depends on the shipment, which is directly related to its viability in the market, and, on the other hand, the market itself involves the exchange of goods and services, which is impossible without shipment.

Georgian transport companies, which do not have the appropriate technical base, can not compete with international transport companies. Because of this, companies are mainly engaged in domestic shipment; 
Georgia does not have a body responsible for the food and transport policy in general, political support is weak, relevant legislation is vague and most of them are incompatible with the European legislative frameworks;

Compared to competitors, Georgia has high shipping rates for sea, land and rail, including terminal services; At the same time, insufficient development of shipment related technological systems leads to a high share of transport costs in total costs. The named factors lead to rising food prices and the loss of the food markets;

No government strategy has been implemented in Georgia for the development of the shipment services;

Innovative shipment infrastructure is missing in the food shipment system and the level of use of digital technology is low.

It is necessary to

- Develop effective mechanisms for political support for food shipment, provide funding policies to ensure a unified chain of shipping and food markets;

- Harmonize rules and standards of managing food shipment with the regulations of other countries, especially with those of European countries;

- Digitalize shipment system, transport corridor and food markets in Georgia;

- Promote investments in the field of shipment and logistics in order to further improve the transport infrastructure;

- Develop transport and logistics centers based on geographical locations of the food markets;

- Improve the security policy of shipped goods;

- Integrate international and regional transport systems;

- Activate economic diplomacy, promote the transit potential of the country by holding respective forums, business meetings and exhibitions, etc.

\section{References}

1. United Nations Economic and Social Commission for Asia and the Pacific. (2015, July 9-10). Concept of Sustainable Transport: Planning and Designing for Sustainable and Inclusive Transportation Systems. National Capacity Building Workshop on Sustainable and Inclusive Transport Development Colombo, Sri Lanka 9-10 July 2015. UNESCAP Transport Division. https://www.unescap.org

2. United Nations Center for Regional Development. (n.d.). Environment Environmentally Sustainable Transport

https://www.uncrd.or.jp/index.php?menu=376

3. Martins V.W.B., Anholon R., Quelhas O.L.G. (2019). Sustainable Transportation Methods. In: W. Leal Filho (ed.) Encyclopedia of Sustainability in Higher Education. Springer, Cham. $\quad$ https://doi.org/10.1007/978-3-030-11352-0 192. https://link.springer.com/referenceworkentry/10.1007\%2F978-3-030-11352-0_192

4. Erkomaishvili, G. (2019). Rational economic policy - Driving force from business to social entrepreneurship . Universal. http://dspace.nplg.gov.ge

5. Danelia I. (2019). Development perspectives of the transit opportunities of geoeconomic hub in Georgia. [Doctoral dissertation, Ivane Javakhishvili Tbilisi State University]. University https://www.tsu.ge/assets/media/files/48/disertaciebi4/Irakli_Danelia.pdf

6. U.S. agency for International Development. (2017, 22 December). Enhancing dialogue platform between public and private sectors in parliament. Research report: Transport and logistics field in Georgia: main challenges and development prospects. USAID Project "Governance for Development". https://pdf.usaid.gov/pdf_docs/PA00TH43.pdf 
7. Campanhola, C., Pandey, Sh. (Eds.). (2019). Sustainable Food and Agriculture, FAO \& Elsevier's Academic Press. https://www.elsevier.com/books/sustainable-food-andagriculture/campanhola/978-0-12-812134-4

8. Sporleder, T. L., Boland, M. A. (2011). Exclusivity of Agrifood Supply Chains: Seven Fundamental Economic Characteristics. The International Food and Agribusiness Management Review, 14(5), 28-51. DOI: $\quad \underline{10.17059 / 2013-4-18}$ https://www.researchgate.net/publication/227354964_Exclusivity of Agrifood_Supply Chains Seven_Fundamental_Economic Characteristics

9. Diosey, R. L. M. (2020). Global Food Security in a Pandemic: The Case of the New Coronavirus (COVID-19): Review. World (1), 171-190.

10. Kharaishvili, E., Natsvlishvili, I. (2019). Markets for Georgian agri-food products and economic policy for export stimulation. Globalisation and Business, (8), 44-53 (in Georgian).

11. Kharaishvili, E. (2017), Directions for improving the supply chain in the agro-food sector of Georgia. In O. Garafonova (Ed.). Foresight management: formation and transformation adaptive business organizations. International collective monograph. (2, 6. pp. 159-169) Kherson: Publishing house Vyshemyrskyi V. S. https://www.tsu.ge/data/file db/economist faculty/shota.pdf

12. National Statistics Office of Georgia. (2020). Share of food expenditures in total consumer spending. Statistical Yearbook of Georgia: 2020. https://www.geostat.ge/media/35685/Yearbook_2020.pdf

13. Pinstrup-Andersen, P. (Ed.) (2015). Food price Policy in an Era of Market Instability: A Political Economy Analisis. Oxford University Press. https://library.oapen.org/bitstream/handle/20.500.12657/32080/617900.pdf? sequence= 1 \&isAllowed $=\mathrm{y}$

14. FAO Committee on World Food Security (2011, July). Price Volatility and Food Security: A Report by High Level Panel of Experts on Food Security and Nutrition. http://www.fao.org/3/mb737e/mb737e.pdf

15. Gelashvili, B. (2020, 19 June). Transportation and warehouse services become more expensive. Report New Agency. https://report.ge/economics/satransporto-dasasatsqobo-momsakhureba-gadzvirda/ (in Georgian)

16. Organisation for Economic Co-operation and Development (OECD). (2020a April). OECD updates G20 summit on outlook for global economy. 27/03/2020 - Updated 15 April 2020. http://www.oecd.org/newsroom/oecd-updates-g20-summit-on-outlook-forglobal-economy.htm

17. The World Bank. (2020a, May). World Bank Group: 100 Countries Get Support in Response to COVID-19 (Coronavirus), 19 May, 2020. IBRD-IDA/World Bank Groop. https://www.worldbank.org

18. The World Bank. (2020b). Annual Report 2020. Supporting Countries in Unprecedented Times. IBRD-IDA/World Bank Groop. https://www.worldbank.org/en/about/annual-report\#anchor-annual

19. Natsvlishvili, I. (2020). Perspectives Of Sustainable Development And Sustainable Business Models In The Post-Covid Era. Globalization and Business, (10), 227-232. https://doi.org/10.35945/gb.2020.10.029 (in Georgian)

20. Rodrigue.J.P. (n.d.). The Logistics of Global Food Systems. The Geography of Transport Systems. The Spatial Organization of Transportation and Mobilit. https://transportgeography.org/contents/applications/logistics-global-food-systems/

21. Liu, S. (2017). Transport and agricultural productivity: A cross-national analysis. Research on Modern Higher Education. (2) Article 01012 https://www.researchgate.net/publication/314219295_Transport_and_agricultural_prod uctivity_A_cross-national_analysis 
22. Wajszczuk, K. (2016). The Role and Importance of Logistics in Agri-Food Supply Chains: An Overview of Empirical Findings. Logistics and Transport, (30), 47-56 https://www.researchgate.net/publication/305478060 The Role and Importance of L ogistics in Agri-Food Supply Chains An Overview of Empirical Findings

23. Gray, R. S. (2020). Agriculture, Transportation and the COVID- 19 crisis. Special Issue: COVID-19 and the Canadian agriculture and food sectors: Thoughts from the pandemic onset, 68 (2), 239-243.

24. Aday, S., Aday, M. S. (2020). Impact of COVID-19 on the food supply chain. Food Quality and Safety, 4 (4), 167-180. https://doi.org/10.1093/fqsafe/fyaa024

25. Organization for Economic Development and Cooperation (OECD). (2020b June 2). Food Supply Chains and COVID-19: Impacts and Policy Lessons. OECD Policy Responses to Coronavirus (COVID-19). http://www.oecd.org/coronavirus/policyresponses/food-supply-chains-and-covid-19-impacts-and-policy-lessons-71b57aea/

26. Borsellino, V., Schimmenti E., Bilali H. El. (2020). Agri-Food Markets towards Sustainable Patterns. Sustainability. 12(60), 2193. https://doi.org/10.3390/su12062193

27. Soma, K., Bogaardt, M.-J., Poppe, K., Wolfert, S., Beers, G., Urdu1, D., Pesce, M., Kirova, M., Thurston, C., Belles, C. M. (2019). Impacts of the digital economy on the food-chain and the CAP: Research for AGRI Committee. https://www.europarl.europa.eu/RegData/etudes/STUD/2019/629192/IPOL_STU(2019) 629192 EN.pdf

28. Gebresenbet, G., Bosona, T. (2012) . Logistics and Supply Chains in Agriculture and Food., In Groznik, A., Xiong, Y. (Eds.). Pathways to Supply Chain Excellence. DOI: 10.5772/25907. https:/www.intechopen.com/books/pathways-to-supply-chainexcellence/logistics-chains-in-food-and-agriculture-sector

29. Ackerley, N., Sertkaya, A., Lange, R. (2010). Food Transportation Safety: Characterizing Risks and Controls by Use of Expert Opinion. Food Protection Trends, 30(4), 212-222. http://www.foodprotection.org/files/food-protection-trends/Apr-10Ackerley.pdf

30. Pal, A., Kant, K. (2017). A Food Transportation Framework for an Efficient and Worker-Friendly Fresh Food Physical Internet. Logistics 1 (10). doi:10.3390/logistics1020010 www.mdpi.com/journal/logistics

31. Dalkmann, H., Sakamoto, K. (2012). Urban Transport: Low Carbon Green Growth Roadmap for Asia and the Pacific. Policy recommendations for the development of eco-efficient infrastructure. https://www.unescap.org/sites/default/files/7.\%20UrbanTransport.pdf

32. Berg, C. N., Deichmann, U., Liu, Y., Selod, H. (2017). Transport Policies and Development. The Journal of Development Studies, 53(5). https://www.tandfonline.com/doi/full/10.1080/00220388.2016.1199857

33. Martincus, C. V., Carballo, J., Cusolito, A. (2017). Roads, Exports and Employment: Evidence from a Developing Country. Journal of Development Economics, 125, 21-39 .

34. IPES Food-International Panel of Experts on Sustainable Food Systems. (2015, May). The New Science of Sustainable Food Systems: Overcoming Barriers to Food Systems Reform. Report 01. The Case for a New Science of Sustainable Food Systems. http://www.ipes-food.org

35. Ministry of Economy and Sustainable Development of Georgia. (2021). Economic outlook, Transport. http://www.economy.ge/?page=ecoreview\&s=26

36. Ministry of Economy and Sustainable Development of Georgia. (2011, August 18). Order \#1-1/1562 of the Minister of Economy and Sustainable Development of Georgia about adoption of technical reglament "rules of cargo shipment by autotransport". http://girca.org/uploads/_122.pdf 
37. Metskhvariashvili, S. (2020, April 15). Shipment became more expensive-will it impact products' prices? Business Media Georgia. https://bm.ge/ka/article/gadazidvebigadzvirda---aisaxeba-tu-ara-es-produqciis-fasze-/54089

38. Government of Georgia. (2020, March 23). Resolution №185 of Georgia’s government about adoption of state program on maintaining prices on basic food products. https://matsne.gov.ge/ka/document/view/4832948?publication $=0$

39. Dorosh, P., Wang, H. G., You, L., Schmidt, E. (2011). Road connectivity, population, and crop production in Sub-Saharan Africa. Agricultural Economics, 43(1), 89-103.

40. Bosker, M., Garretsen, H. (2012). Economic Geography and Economic Development in Sub-Saharan Africa. The World Bank Economic Review, 26(3), 443-484.

41. Ghani, E., Goswami, A. G., Kerr, W. R. (2016). Highway to Success: The Impact of the Golden Quadrilateral Project for the Location and Performance of Indian

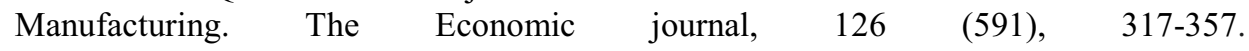
https://doi.org/10.1111/ecoj.12207

42. Kvasha, S., Pankratova, L., Koval, V., \& Tamošiūnienė, R. (2019). Illicit financial flows in export operations with agricultural products. Intelellectual Economics, 13(2), 195-209.

43. Kvach, Y., Piatka, N., \& Koval, V. (2020). Management of sustainable entrepreneurship adaptation to tax changes in environmental investment. Baltic Journal of Economic Studies, 6(5), 96-105. https://doi.org/10.30525/2256-0742/2020-6-5-96-105

44. Derii Zh., Koval, V., \& Sedikova I. (2018). The role of the agricultural sphere in the context of food security. Scientific Bulletin of Polissia, 4(16), 21-27. http://dx.doi.org/10.25140/2410-9576-2018-4(16)-21-27 